\title{
Evaluation of feasibility and development strategy of white shrimp enlargement business at Dukuhtunggal village Glagah sub district Lamongan
}

Ika Maulana Lutfi ${ }^{1}$, David Hermawan ${ }^{1}$, Anis Zubaidah ${ }^{1 *}$

Fisheries Department, Faculty of Agriculture and Animal Science, University of Muhammadiyah Malang, Indonesia.

*aniszubaidah@umm.ac.id

https://doi.org/10.22219/ijota.v1i1.6077

\begin{abstract}
The aim of this study was to analyze the financial feasibility and formulating business development strategies enlargement White shrimp at Dukuhtunggal Village Sub district Glagah Lamongan. This study was conducted in September to October 2017. The research method was used the survey method. The sampling method was performed using methods of snowball sampling by the number of respondents as many as 18 people. The result showed that the business of white shrimp enlargement need to be implemented and developed, because the results of the assessment in accordance with the investment criteria Net Present Value (NPV) reached Rp 283.927.334, Net Benefit Cost Ratio (Net/B/C) by 28, Internal Rate of Return (IRR) reached $645.5 \%$, the value of payback period of 0.37 or three months of seven days and the Profitability index (PI) of 1.53 . Business development strategy is known through proceeds from the matrix IFE and EFE with a total score of 3.341 and 3.272. Matrix IE shows the position of the company located on the cell to one which means growing and building. While the intensive strategy i.e., market penetration, market development, product development and integration strategies was applied to support it. The formulation of the strategy produces eight alternative development strategies i.e., increasing in production capacity, strengthening the institutional role, leveraging capital access, empowerment of farmers, increasing the use of quality seeds, weaving cooperation with suppliers, maintaining the condition of the infrastructure, and improving the implementation and monitoring of standard operational procedures.
\end{abstract}

Keywords: Vannamei Shrimp, Feasibility of Business, SWOT

\section{Introduction}

Lamongan is one of the regions with geographical and ecological conditions of the potential for the development of the fishing industry as a minapolitan with the capture fisheries sector development and cultivation. Potential sectors of aquaculture fish farming were developed in the brackish and fresh water. Currently, some commodities cultivation are being developed in Lamongan including white shrimp, grouper, milkfish, tilapia, catfish, and Oreochromis mossambicus. Production 
in 2013 was increased 39,189 tonnes and reached 46.605 tons in 2015 or raised in 19 percent (BPS Lamongan, 2015). White shrimp became the leading commodity developed aquaculture Minneapolitan programs in Lamongan.

One of the constraints in the development of aquaculture is the need of capital investment. The support of the local government agencies and financial institutions in making public policy are instrumental in the success of aquaculture in Lamongan. This research aimed to know the feasibility of financial and business development strategy for enlarging white shrimp at Dukuhtunggal village Sub-district Glagah Lamongan.

\section{Materials and Methods}

This study used a surveying method. The process of survey included covering the location, collecting data, and tabulating data on local business activities enlargement white shrimp at the village of Dukuhtunggal Sub-district Glagah Lamongan.

Respondent's research were consisted of cultivator and expert respondents. The cultivator respondents determined of snowball sampling technique with key informants assistance. The number of respondents were obtained about 18 people based on white shrimp commodity which has an area in acre, and its cultivation conducted every year. The five expert respondent were determined by their interests and/or competence and/or influence in determining the direction of fisheries development in the Dukuhtunggal village. Respondents were interviewed at local office of fisheries Glagah sub-district unit of technical management that is formed by head and Deputy Pokdakan Mina Mandiri and two other members of Pokdakan Mina Mandiri.

\subsection{Business Feasibility Analysis}

Feasibility of white shrimp enlargement business was analyzed on two approaches, the qualitative and quantitative analysis. The aim of the qualitative analysis is to obtain an overview of business feasibility in terms of market aspects, the technical aspects, the risk management certification council, the environmental aspect and social aspects. While the quantitative analysis aims to understand investment feasibility of white shrimp enlargement business based on the criteria are consisted Net Present Value (NPV), Net Benefit Cost Ratio (Net B/C), and Internal Rate of Return (IRR) (Gittinger, 1986 in Prasetio. 2016).

\subsection{SWOT Analysis}

SWOT is a means of identifying systematically in the internal factor including strengthens and weakness and external factors including opportunities and threats (David, 2009). A process must go through an analysis obtained through more precise necessary steps (Marimin, 2004 in Goimawan, 2012):

a) The stage of receipting data and evaluation of external factors and internal factor (EFE/IFE).

b) The stage of analysis for making matrix internal-external and matrix SWOT.

c) The formulation strategy.

\section{Results and Discussion}

\subsection{Characteristics of respondents}

According to the interviews, obtained a characteristic of the cultivator of them as follows: 
a. Cultivator of the Age

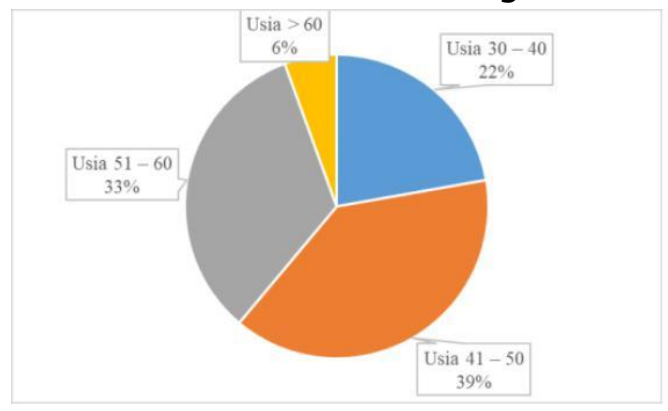

c. Experience Business

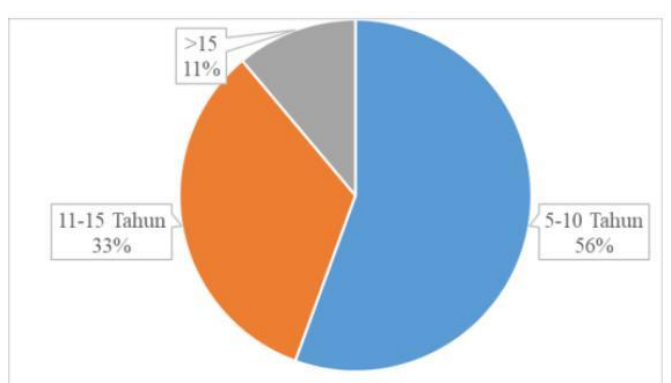

b. Education Levels

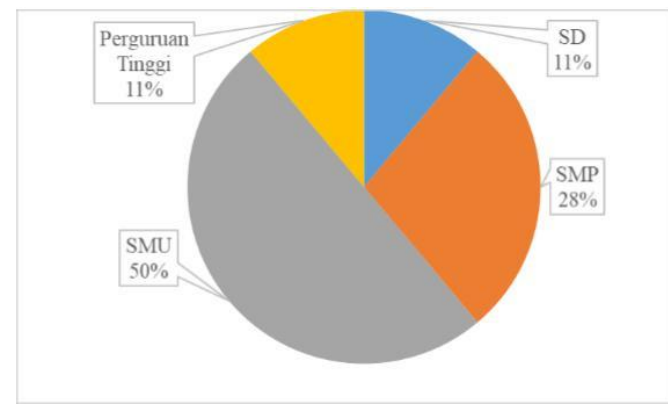

d. Status Land Ownership

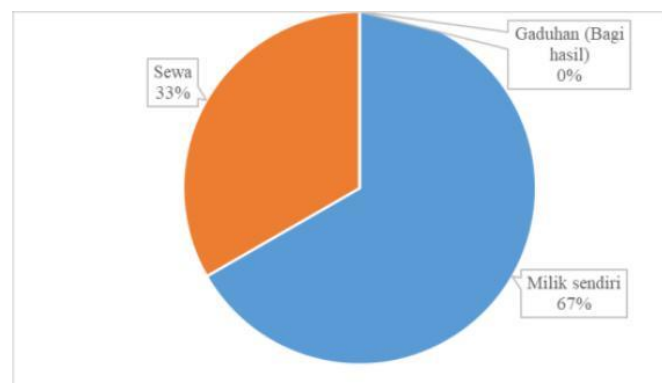

Figure 1. Characteristic of responden

\subsection{Feasibility Analysis}

\subsubsection{Marketing Aspects}

The demand for white shrimp usually are obtained from intermediary traders and the community in general. The white shrimp are marketed Rp. 55,000.00/kg consisted 60-120 shrimp in range. The vanamei shrimp was distributed directly from farmers to distributors, especially in sub-district of Glagah. From there, the sales distributed white shrimp into various areas, including fish market in Lamongan, Gresik, Surabaya and supplying companies and exporters. Market feasibility analysis is related an effort of demand for a product, the selling price of a product, potential and market share, as well as marketing strategies and the estimated sales that could be achieved by an undertaking (Gittinger, 1986 in Prasetyo, 2016).

\subsubsection{Technical Aspects}

The technical aspects of white shrimp enlargement scale as in traditional village Dukuhtunggal covered in the location of economic activities, the production process, and the technology were used.

\section{a. Business Location}

White shrimp enlargement business was carried out at Dukuhtunggal Village sub-district of Glagah Lamongan. The location became the center of the nursery because white shrimp could potentially be farmed in paddy fields pond area and have functions as the traditional scale of aquaculture with the pattern polyculture.

b. Enlargement activity

- Ponds preparation 
The preparation of pond is conducted by drying of land, removing of mud in the pond, improving plug as well as improving of pond.

- Liming and fertilizing

Liming ponds was done once a year after processing land or cultivation. The doses of fertilizer was used as many as $200-300 \mathrm{~kg} / \mathrm{ha}$. Fertilization of ponds was carried out using organic fertilizers and non-organic. Organic fertilizers was used about 200-300 kilograms per hectare, while fertilizer inorganic (TSP) was used about 150 kilograms per hectare and urea, 75 kilograms per hectare. Non-organic fertilizer was used in every the planting season so that in the one year was done three-time with non-organic fertilizer. The TSP (Triple Super Fosfat) is a source of phosphorus element that is degraded in water and possess $\mathrm{P}_{2} \mathrm{O}_{3}$ levels up to 45 percent.

- Irrigation

Irrigation was done on the land pond after fertilizing for growing natural feed and using the land as a medium cultivation. The depth of the water pond was set as high as 70-100 $\mathrm{cm}$. The land pond is cistern rain and water filling pond using water pump through the irrigation spring technical and irrigation water obtained from Bengawan Solo.

- Procurement of seeds

Origin shrimps and fish were obtained from the hatchery at Lamongan district. The stocking density of white shrimp seeds were $50.000-100.000$ or $10-20$ rean per hectare or 5-10 per square meters. White shrimp seeds were used with the PL 10 - PL 12 obtained from hatchery that had received recommendation free pathogenic, Specific Pathogen Free (SPF).

- Maintenance

The fluctuation of $\mathrm{pH}$ was controlled by addition of fertilizer Urea and TSP as many as 5 to 10 percent and also stabilized of plankton in ponds. In addition, probiotics was given on the day 70 to support natural feed (plankton) that had dropped or growing of shrimp. The feed was given with 2-5 percent of shrimp biomass.

- Harvest

Harvest 100-110 was conducted after the age of maintenance. Preferential treatment before harvest was giving dolomite $80 \mathrm{~kg}$ per hectare and maintained the level of water during the day in order to 2-4 to shrimp had not molted in time.

\subsubsection{Management Aspects}

The risk management certification council basically is assess the organizer of business and the structure organizations (Rubiana, 2010). The management system in the village Dukuhtunggal was considered to be a simple individual business. Cultivator targeted their business individually and they had a role as the owner of their business (managers) and responsible for white shrimp enlargement. Generally, cultivators do not have an energy to assist in the management of a business. The business of cultivation was made as a basic business so that the cultivator had a directly responsible for running the management business activities.

\subsubsection{Social Aspect}

The business of cultivating white shrimp at Dukuhtunggal village has an important role in the lives of the surrounding community social. The activity of aquaculture gives a job opportunities for 
nearby residents. It decrease the unemployment rate and raise the income of the surrounding community.

\subsubsection{Financial Aspect}

The analysis of this financial is based on the criteria investment including Net Present Value (NPV), Net Benefit Cost (Net B/C), Internal Rate of Return (IRR) dan Payback Period (PP) arranged in cash flow to know the benefits received and expenses incurred by cultivator at Dukuhtungal Village.

a. Inflow

- Production and income

The average production was resulted from white shrimp cultivation using polyculture system in one season, white shrimp as much as $400 \mathrm{~kg}$ fish, milkfish as much as $430 \mathrm{~kg}$ tilapia as much as $600 \mathrm{~kg}$. The average selling price of each commodities were white shrimp, Rp 55,000, milkfish, Rp 16,000, and tilapia, Rp. 14,000. While the revenue were obtained Rp. 22 million per season for white shrimp, Rp 6,880,000 per season for milkfish, and Rp 8.4 million per season for tilapia. So the revenue average in one season were $\operatorname{Rp} 37,280,000.0$ and in one year with three planting season were earned about Rp 111,840,000.

- Residual value

Residual value was obtained from the rest of the unused investment capital depleted during the age of business. On the research of the residual value of the investment was obtained in the $10^{\text {th }}$ year of $\operatorname{Rp~3,037,500.~}$

Table 1. Residual value

\begin{tabular}{|c|c|c|c|c|}
\hline No & Description & $\begin{array}{c}\text { Technical age } \\
\text { (Year) }\end{array}$ & $\begin{array}{l}\text { Price } \\
\text { (Rp) }\end{array}$ & $\begin{array}{c}\text { Residual value } \\
\text { (Rp) }\end{array}$ \\
\hline $\begin{array}{l}1 \\
2 \\
3\end{array}$ & $\begin{array}{l}\text { Water pump } \\
\text { Building } \\
\text { Other equipment } \\
\text { a. Plastic drum } \\
\text { b. Harvest Basket } \\
\text { c. Dipper } \\
\text { d. Bucket } \\
\text { Total }\end{array}$ & $\begin{array}{l}4 \\
3 \\
2 \\
2 \\
\end{array}$ & $\begin{array}{r}200.000 \\
175.000 \\
100.000 \\
100.000 \\
\mathbf{6 . 0 7 5 . 0 0 0}\end{array}$ & $\begin{array}{r}1.500 .000 \\
1.250 .000 \\
\\
100.000 \\
87.500 \\
50.000 \\
50.000 \\
\mathbf{3 . 0 3 7 . 5 0 0}\end{array}$ \\
\hline
\end{tabular}

b. Current Costs

- Investment Cost

The investment cost is the cost that farmers spent to start white shrimp polyculture businesses combined milkfish. Investment activities included the purchase of a water pump, home guard and cultivation equipment purchases and was calculated in Rp 6,075,000.

- Variable cost

The cost of a variable is an expense spent which could increase or reduce output and will undergo a change if the volume of production changed (Soekartawi, 1995 in Prasetio, 2016). The variable costs were incurred in the enlargement of the white shrimp polyculture combined with milkfish including the cost of purchasing the white shrimp seed, milkfish seed, tilapia seed, fertilizer, lime, shrimp feed, fish feed and fuel oil. Total average variable costs 
were incurred in the enlargement effort white shrimp pattern polyculture in the village of Dukuhtunggal as many as Rp 19,671,000 per season or reached Rp 59,013,000 per year.

Table 2. Investemen Cost

\begin{tabular}{llcrrr}
\hline No & \multicolumn{1}{c}{ Description } & Unit & Amount & $\begin{array}{c}\text { Unit price } \\
\text { (Rp) }\end{array}$ & \multicolumn{1}{c}{$\begin{array}{c}\text { Total cost } \\
\text { (Rp) }\end{array}$} \\
\hline 1 Water pump & Unit & 1 & 3.000 .000 & 3.000 .000 \\
2 Building & Unit & 1 & 2.500 .000 & 2.500 .000 \\
3 Other equipment & & & & \\
a. Plastic drum & Buah & 4 & 50.000 & 200.000 \\
b. Harvest Basket & Unit & 5 & 35.000 & 175.000 \\
c. Dipper & Unit & 5 & 20.000 & 100.000 \\
d. Bucket & Unit & 5 & 20.000 & 100.000 \\
\hline Total & & & & $\mathbf{6 . 0 7 5 . 0 0 0}$ \\
\hline
\end{tabular}

Table 3. Variable Cost

\begin{tabular}{llrr}
\hline No & Description & $\begin{array}{c}\text { Amount of money } \\
\text { (Rp/Period) }\end{array}$ & \multicolumn{2}{c}{$\begin{array}{c}\text { Amount of money } \\
\text { (Rp/Year) }\end{array}$} \\
\hline 1 Fish seed & & \\
a. Whiteleg shrimp & 2.500 .000 & 7.500 .000 \\
b. Milkfish & 2.000 .000 & 6.000 .000 \\
c. Tilapia & 500.000 & 1.500 .000 \\
2 Feed & 3.990 .000 & 11.970 .000 \\
a. Whiteleg shrimp & 7.000 .000 & 21.000 .000 \\
b. Fish & 1.890 .000 & 5.670 .000 \\
c. Probiotic & & \\
Fertilizer & 100.000 & 300.000 \\
a. Organic & 676.000 & 2.028 .000 \\
b. Urea & 300.000 & 900.000 \\
\hline c. Sp 36 & & \\
\hline
\end{tabular}

\section{- $\quad$ Fixed costs}

Fixed cost is the cost that its magnitude is not dependent on the amount of production. Fixed costs include rent and purchase of aquaculture tools, while variable costs include the cost of seeds, the cost of fertilizer, pesticide, and the costs including labor expenses are paid based on the calculation of volume production (Erhans, 2000). The fixed cost average total were obtained as many as Rp 13,432,000 per year in the village of Dukuhtunggal for cultivating of white shrimp. Fixed costs were incurred in cultivation including the rental cost of ponds, fishponds, the tax cost of ponds, improvement of labor wage pre-production, wage labor of harvesting and packing.

- Eligibility criteria for Investment

Based on the calculation on business of white shrimp enlargement with polyculture patterns in the village Dukuhtunggal, NPV value was Rp 283.852.334 that showing the present value of income was positive for ten years the interest rate six percent. The value of Net B/C showed 28 in value that means net income received larger than 28 times. It could be defined that every rupiah will give benefits 28 rupiah. The exact value was obtained by means trial and error count on the 
perceived value of interest rate (i) the reduction to get an NPV positive and negative approaches 0 (zero).

Table 4. Fixed cost

Amount of money Amount of money

No Descriptions

1 Rent pond

2 Depreciation cost

3 Tax

(Rp/Period)

4 Pay wages

$\begin{array}{lrl}\text { a. Pond improvement } & 300.000 & 900.000\end{array}$

b. Harvest $\quad 600.000$

1.800 .000

c. Packing

300.000

900.000

Amount

1.200 .000

13.342 .000

The smallest NPV were positive factors with a discount the total in 64.5 percent and a negative value NPV smallest was a discounts factors from 65 percent, to as much as 645.5 percent. The value of them showed that the capacity of repaying capital was greater than the level of the discount rate used. The value of the payback period was obtained as much as 0.37 comprised between Rp. 14.475.000 with acceptance of Rp. 39.361.750 per year on the average. Based on the equity value of the payback period could be done in 3 months and 7 days. The profitability index were obtained from subtracting between cash in, Rp. 1.121.437.500 with other cash out, Rp 733.895.000. It obtained a positive value or 1.53 larger than 1 , thus investment of white shrimp enlargement business in the village Dukuhtunggal need to be executed.

\subsection{Development strategies}

\subsubsection{Identification of the environment strategic}

Identification of fishery commodities was based on environment development of white shrimp enlargement at Dukuhtunggal Village including the internal and external environment. The internal environment is all the factors in the scope of aquaculture business in the village of Dukuhtunggal, i.e., natural resources, fisheries, human resources institutional supporters, production, and finance. The external environment includes a factor of economic, social and cultural as well as other elements outside the internal environment.

\subsubsection{Evaluation of the Strategic factors of IFE and EFE}

IFE matrix analyzing internal strategy consisting of strengths and weaknesses is the formulation of the strategy of summarizing and evaluating the main strengths and weaknesses in the areas of business functions and became the Foundation for identifying them as well as the evaluation relationship between these areas. Analysis of IFE matrix can be seen as in table 5 as follows.

After getting a score of internal factors that a need to do an analysis of external factors which include business opportunities and threats, white shrimp enlargement continued with the filling of the questionnaire for weighting and performed in the ranking factor external data obtained external matrix that could be seen in table 6 . 
Table 5. Internal Factor Evaluation

\begin{tabular}{|c|c|c|c|c|}
\hline No & Faktor Strategi Internal & Weights & Rating & Score \\
\hline \multirow[t]{7}{*}{1} & Strength & & & \\
\hline & Potential Land & 0,136 & 3,4 & 0,463 \\
\hline & The Potential For Farmers & 0,122 & 4,0 & 0,490 \\
\hline & Institutional cultivators & 0,109 & 3,2 & 0,348 \\
\hline & Vaname Shrimp Commodity Excellence & 0,075 & 2,8 & 0,210 \\
\hline & The Condition Of The Infrastructure & 0,102 & 2,2 & 0,224 \\
\hline & The total value of strength & & & 1,735 \\
\hline \multirow[t]{8}{*}{2} & Weakness & & & \\
\hline & The ability of the capital & & & \\
\hline & Knowledge management of cultivation (CBIB) & 0,082 & 2,8 & 0,229 \\
\hline & The number of seeds limited-quality shrimp & 0,136 & 4,0 & 0,544 \\
\hline & Cultivation Technology Of Usage & 0,122 & 3,6 & 0,441 \\
\hline & & 0,116 & 3,4 & 0,393 \\
\hline & The total value of weaknesses & & & 1,607 \\
\hline & $\begin{array}{l}\text { Total IFE } \\
\text { Gap of IFE }\end{array}$ & 1,00 & & $\begin{array}{l}3,341 \\
0,128\end{array}$ \\
\hline
\end{tabular}

Table 6. Matrik EFE Analysis (External Factor Evaluation)

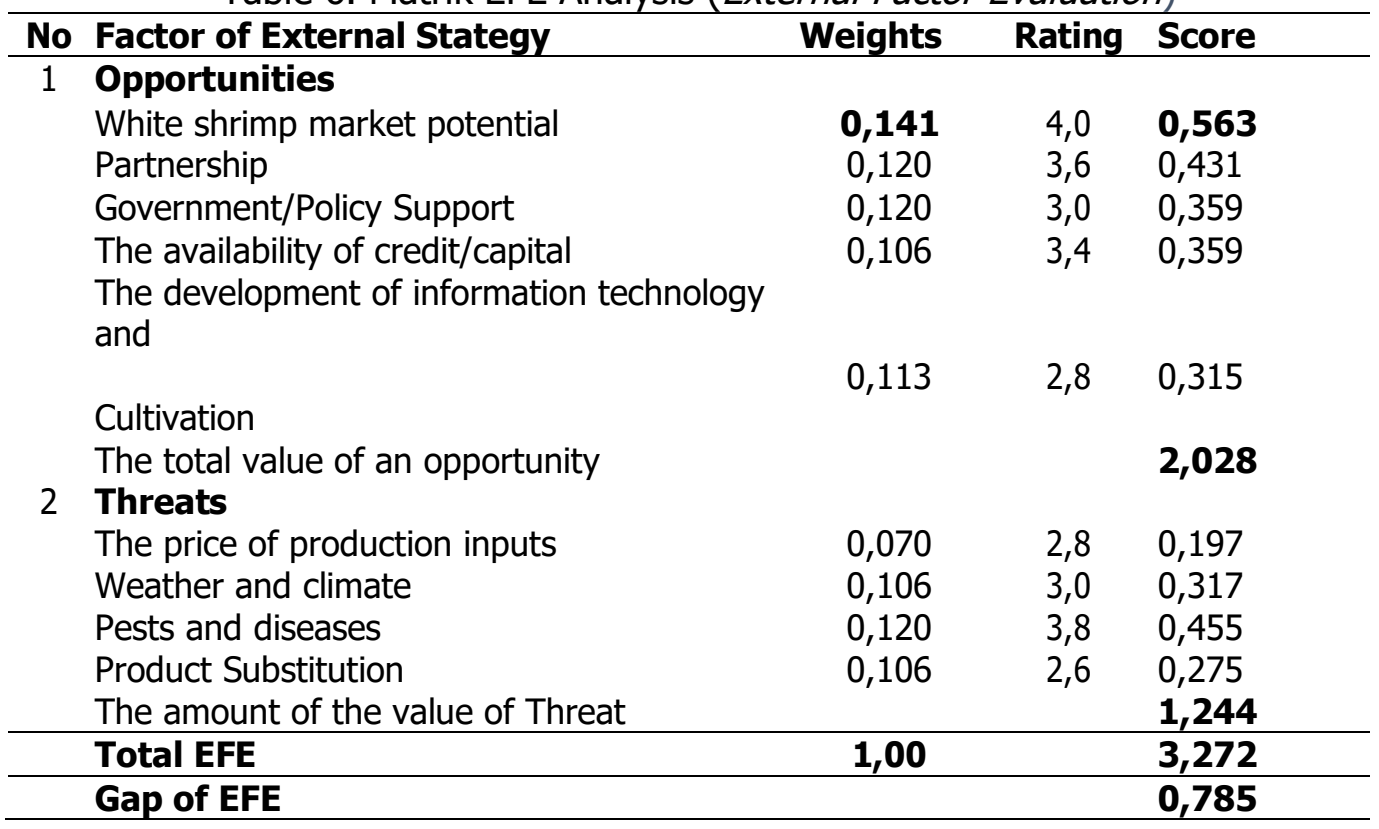

\subsubsection{Matrix IE (Internal-external)}

IE matrix was based on two key dimensions that are the point of the $x$-axis coordinate value presented the IFE and the $y$-axis coordinate value presented the EFE. Search the point coordinates in the image matrix diagram of IE was done by summing the internal factors $(1.601+1.747)$ and external factors $(2.028+1,244)$. So the retrieved value of the internal and external value of 3,341 3,272 was put in cultivating of white shrimp in the village of Dukuhtunggal on the cell's position to a position in the matrix I. IE is shown in Figure 1 as follows. 


\begin{tabular}{|c|c|c|c|c|}
\hline \multirow[b]{3}{*}{ Tinggi } & \multicolumn{2}{|r|}{ Kuat } & $\begin{array}{l}\text { ot Skor IFE } \\
\text { Sedang }\end{array}$ & Lemah \\
\hline & 4,0 & 3,0 & 2,0 & 1,0 \\
\hline & 3,0 & $\begin{array}{l}\text { Grow and Build } \\
\text { (I) }\end{array}$ & $\begin{array}{l}\text { Grow and Build } \\
\text { (II) }\end{array}$ & \\
\hline Sedang & 2,0 & $\begin{array}{l}\text { Grow and Build } \\
\text { (IV) }\end{array}$ & & \\
\hline Rendah & 1,0 & & & \\
\hline
\end{tabular}

Figure 2. Matrix IE (Internal-Eksternal)

\subsubsection{The formulation of the strategy}

Analysis of the formulation of the strategy was the matching stage to produce an alternative strategy involving strength, weaknesses, opportunities, and threats that had been set before. Formulation of business strategy can be seen in table 7 .

Table 7. SWOT Analisys

\begin{tabular}{|c|c|c|}
\hline EFAS & $\begin{array}{l}\text { Strength }(\mathrm{S}) \\
\text { 1. The potential of the Land } \\
\text { 2. The potential of Farmers } \\
\text { 3. Institutional Cultivators } \\
4 \text {. Advantages of commodity } \\
\text { white shrimp } \\
5 \text {. The condition of the } \\
\text { Infrastructure }\end{array}$ & $\begin{array}{l}\text { Weaknesses (W) } \\
\text { 1. The ability of the capital } \\
\text { 2. Knowledge of cultivation } \\
\text { management (CBIB) } \\
\text { 3. low seed Quality } \\
\text { 4. The use of Aquaculture } \\
\text { Technology }\end{array}$ \\
\hline $\begin{array}{ll}\text { Opportunities (O) } \\
\text { 1. } & \text { Market potential } \\
\text { 2. } & \text { Paname Shrimp } \\
\text { 3. } & \text { Support } \\
\text { 3ortip } \\
\text { 4. } \\
\text { 5. } & \text { Availability of Credit } \\
& \text { cultivation technology } \\
\end{array}$ & $\begin{array}{l}\text { Strategi S-O } \\
\text { 1. Increasing the production } \\
\text { capacity of } \\
\text { 2. Strengthen the institutional } \\
\text { Role }\end{array}$ & $\begin{array}{l}\text { Strategi W-O } \\
\text { 1. Utilize the access to capital } \\
\text { 2. Empowerment of farmers } \\
\text { 3. Increasing the use of quality } \\
\text { seeds }\end{array}$ \\
\hline $\begin{array}{l}\text { Threats }(\mathbf{T}) \\
\text { 1. The price of production } \\
\text { inputs } \\
\text { 2. Weather and climate } \\
\text { 3. Pests and diseases } \\
\text { 4. product Substitution }\end{array}$ & $\begin{array}{l}\text { Strategi S-T } \\
\text { 1. Enhance cooperation with } \\
\text { suppliers } \\
\text { 2. Maintain the condition of } \\
\text { the infrastructure }\end{array}$ & $\begin{array}{l}\text { Strategi W-T } \\
\text { 1. Improve the implementation } \\
\text { and monitoring of standard } \\
\text { Operational procedures } \\
\text { (SOP) }\end{array}$ \\
\hline
\end{tabular}

\section{Conclusions and Suggestion}

\subsection{Conclusion}

The result of the non-financial aspects of market aspects, technical aspects, management aspects and social aspects showed that the cultivation of white shrimp at Dukuhtunggal village deserves to be implemented and developed. The financial aspect is an investment criteria e.g. Net Present Value (NPV) reaching 283,927,334, Net Benefit-Cost ratio (Net/B/C) by 28, Internal Rate of Return (IRR) reaching $645.5 \%$, Payback period value of 0.37 or 3 months and 7 days and the value of Profitability index (PI) of 1.53. 
Matrix analysis of the strategy suggests that the condition is on the cell enlargement effort to I tend to support strategies to grow and build. Based on the matrix formulation of the strategy, it obtained eight strategies so that the alternative strategy of business development at Dukuhtunggal village i.e. an increasing in production capacity, strengthening the institutional role, utilizing access capital, empowerment of cultivator, increasing the use of quality seeds, partnering with suppliers, maintaining the condition of the infrastructure, and improving the implementation and monitoring of standard operational procedures (SOP).

\subsection{Suggestion}

Businesses of white shrimp enlargement at Dukuhtunggal Village Glagah Sub district Lamongan, POKDAKAN MINA MANDIRI need to be continually improved by cooperating with the pertinent stakeholders in conducting the activities of socialization, training and the development of aquaculture technology.

\section{References}

BPS Lamongan, (Badan Pusat Statistik). 2015. Lamongan Dalam Angka. https://lamongankab.bps.go.id. Diakses tanggal 10 Juli 2016.

David. 2009. Manajemen Strategis: Konsep. Ed Ke-12. Paulya Sulistio dan Dono Sunardi, Penerjemah. Jakarta: Salemba Empat. Terjemahan Dari Strategic Management.

Erhans A. 2000. Akuntansi Berdasarkan Prinsip Akuntansi Indonesia. PT.Ercontara Rajawali: Cirebon.

Gittinger JP. 1986. Analisis Ekonomi Proyek-Proyek Pertanian. Sutomo S, K. Mangiri, penerjemah. Jakarta (ID): Universitas Indonesia Press.

Gofur A. 2013. Analisis Potensi Permintaan, Penawaran Susu Segar dan Kelayakan Investasi untuk Klaster Peternakan Sapi Perah Sebagai Strategi Pengembangan Kawasan Sapi Perah di Kabupaten Jember, Jurusan Ekonomi dan Studi Pembangunan Fakultas Ekonomi Ubiversitas Jember. Jember Jawa Timur.

Hamdani. 2014. Analisis Kelayakan Usaha Pembesaran Kepiting Soka di Balai Pengembangan Budidaya Air Payau dan Laut (BPBAPL) Karawang, Kabupaten Karawang [skripsi]. Bogor (ID): Institut Pertanian Bogor.

Prasetio T. 2016. Estimasi Nilai Ekonomi Dan Analisis Kelayakan Usaha Budidaya Tambak Polikultur (Studi Kasus: Desa Tambaksari, Kecamatan Tirtajaya, Kabupaten Karawang). Skripsi Fakultas Ekonomi dan Manajemen Institut Pertanian Bogor. Bogor.

Rangkuti F. 2008. Analisis SWOT: Tekhnik Membedah Kasus Bisnis. Reorientasi Konsep Perencanaan Strategis Untuk Menghadapi Abad 21. Jakarta: Gramedia Pustaka Utama.

Sutedjo MM, Kartasaputra AG. 1990. Pupuk dan Pemupukan. Rineka Cipta, Jakarta. Suwarsono. 2000. Studi Kelayakan Proyek. UPP AMP YKPN. Yogyakarta Umar, H. 2005. Studi Kelayakan Bisnis Edisi-3. PT. Gramedia Pustaka Utama. 